\title{
THE SOUND OF THAUMA: MUSIC AND THE MARVELLOUS
}

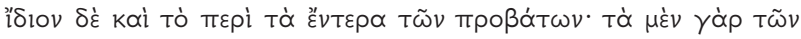

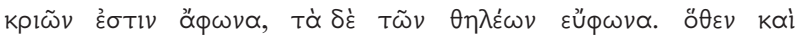

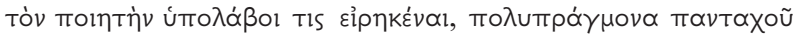

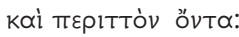

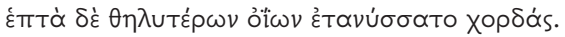

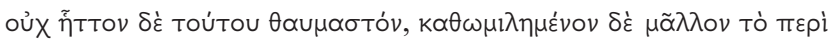

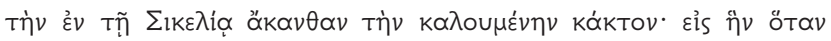

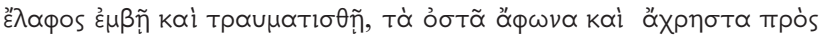

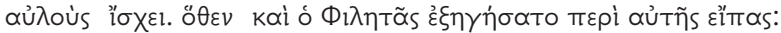

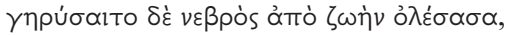

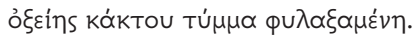

This property of the entrails of livestock is also strange: the entrails of rams are unmelodious, while those of ewes are melodious. From this it is possible to understand what the poet [i.e. Homer], who is in all respects desirous of knowledge ${ }^{\mathrm{I}}$ and painstaking, said: 'He strung it with seven gut-strings from female sheep' [= hHerm. 5I]

And no less marvellous than this, but even better known, is this fact concerning the prickly plant in Sicily called 'cactus'. Whenever a deer treads upon this plant and is wounded, its bones become unmelodious and useless for the manufacture of auloi. For this reason Philitas expounds on this plant when he says: 'Let the fawn which has lost its life sing, the fawn which has avoided the sting of the sharp cactus' [= Philitas fr. $\mathrm{I} 8 \mathrm{Sb}$.]

Antigonus of Carystus, Collection of Marvellous Investigations 7-8

I While the adjective polupragmon most often denotes the quality of being 'meddlesome' or 'a busybody' in a negative sense, in certain cases, usually in the context of scholarly activity as in this example from Antigonus, it points to a more positive sense of curiosity and desire for further knowledge: see Leigh (20I3) on these various shades of meaning. 
In the opening of Antigonus' Collection of Marvellous Investigations it is not the scientific intricacies of Aristotle's zoological works which are thrust to the forefront of the reader's attention, but rather the world of the music and poetry of the past. A group of eight thematically connected marvels speak back and forth to each other on the subjects of music, voice and voicelessness. The first entry is derived from Timaeus, who reports that 'cicadas sing on the Locrian side of the river Halex, but remain

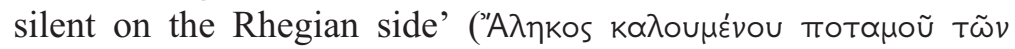

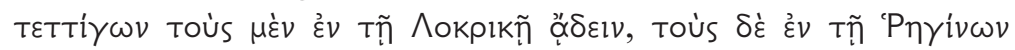

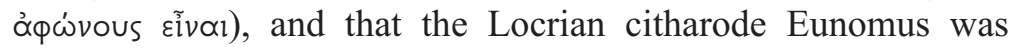
aided in a contest at Delphi with the Rhegian citharode Ariston

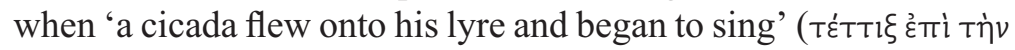

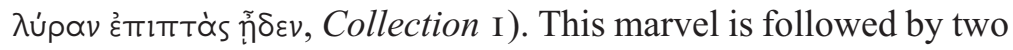
further reports about these singing insects. The first also relates to Rhegion and informs us that 'when he was somewhere in this region Heracles, who was trying to sleep, was annoyed by the sound of the cicadas and prayed for them to become voiceless'

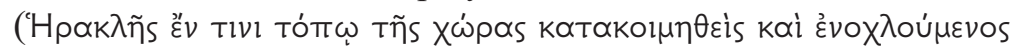

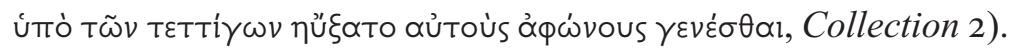
The next marvel moves away from south Italy, informing us that 'in Cephallenia too a river separates out two banks: on one bank cicadas are present, on the other they are absent' (кøi $\varepsilon v$

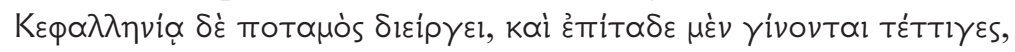

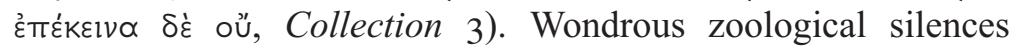
remain the focus of the next entry, which tells us that 'frogs in

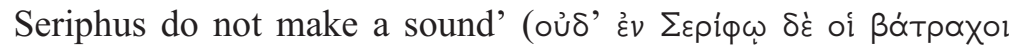
$\phi \theta \varepsilon \dot{\gamma} \gamma$ ovtal, Collection 4). This focus on silence strongly contrasts with the subsequent entry, a report from Myrsilus of Methymna concerning marvellously noisy birds in Lesbos near the tomb of Orpheus' head in Antissa: in this place 'the nightingales are more

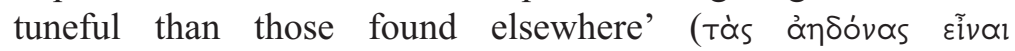

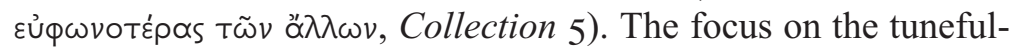
ness of certain birds continues in the next entry about partridges in Attica and Boeotia: 'some are melodious while others are com-

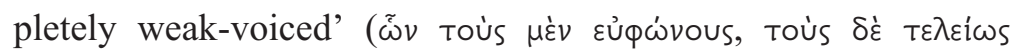

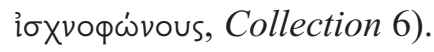


The final two entries (7-8) in Antigonus' initial grouping of marvels, cited in full above, demonstrate in an especially pointed form the paradoxographer's multi-layered engagement with the thaumatic power of both the oral and written poetry of the past. The successive citations from the Homeric Hymn to Hermes and from the work of the early Hellenistic poet Philitas of Cos once again reveal the paradoxographer's typically Hellenistic interest in literary games involving his source texts, a phenomenon which was explored in the previous chapter. At the beginning of the present chapter I want to build on this discussion further by examining the reasons behind Antigonus' inclusion and juxtaposition of these two particular poetic citations within the opening section of his paradoxographical collection.

Antigonus is interested in the hHerm. as a text which allows him to play upon the connection between thauma and music as it is reflected in both the poetic and the scientific traditions. The hymn is an especially apt text for Antigonus to include in his marvel-collection. Out of all the texts in our extant corpus of Homeric hymns, this one is by far the most explicitly thaumatic. Thauma is an almost constant reaction to Hermes' activities and achievements, starting from the moment of his birth, and it is the ability to see the marvellous potential of the familiar material of the world around him, and to make use of the marvellous in the everyday, which enables the infant god to prove his divine parentage. Hermes' most marvellous invention of all, the lyre, is inherently imbued with the ability to provoke thauma in an audience in every single performance. As an instrument created out of the everyday familiar material of nature, which goes on to produce exceptional marvels of culture, the lyre is depicted as an object which transcends established boundaries and simultaneously creates new links between previously unconnected realms. Perhaps the most important areas which the lyre is able to connect in new ways within the Hymn are the separate realms of god and man. We see this in action in the poem itself during Hermes' two musical performances, each of which has an explicitly marvellous effect within the narrative, hinting at the complex interrelationship between musical performance, thauma and the boundaries between gods and mortals.

This effect is complicated in the second half of the Hymn, when Hermes' second musical performance even manages to provoke wonder in a fellow god, his elder brother Apollo. Mortals often 
marvel, especially at divine epiphanies, but this portrayal of a god's marvelling response is extremely unusual. It hints at the significant place the lyre is presented as occupying not only in the relationship between gods and humans but within the everyday experience of both. As I will show below, by the end of the narrative the Hymn has thus given us an aetiology not only of the lyre's existence but also of its intensely thaumatic effect. In fact, the effect of thauma is continually associated with aetiological accounts of the origins of various musical and choral genres in the Greek tradition. This is a theme which will be explored further in this chapter's final section as I move onto the broader connections between thauma, music, song and choreia (song-dance) in Odyssey 8 and the Delian half of the Homeric Hymn to Apollo as case studies of the interconnections between all of these elements in the Greek poetic and musical tradition. The importance of thauma in Greek conceptions of music and song will become even clearer in the final case study at the end of this chapter, which turns to the presentation of another wondrous musical performance: Herodotus' epiphanic and godlike vision of the citharode Arion in the Histories. But before reaching back and further examining the relationship between thauma, music and song from early Greek hexameter poetry onwards, I will now return to Antigonus' reception and appropriation of the intensely thaumatic impact of music in his own marvel-collection.

\section{I Homer the Proto-Paradoxographer: Poetry, Music and Science in Antigonus' Collection of Marvellous Investigations}

For Antigonus, hHerm. is an ideal text through which to explore how familiar, everyday aspects of the natural world around us are able to induce thauma. In this respect, the paradoxographer has picked up on the potential of this poem to stand as an antecedent to his own poetics: just as the Hymn describes the combination of disparate parts of everyday nature to produce a stunning instrument of thaumatic effect, so too does Antigonus' own work involve the dismemberment and reassembly of previous poetic and scientific texts, which are then bound together to induce wonder in the reader. Perhaps this is why Antigonus is so keen 
to cast the poet of hHerm. - whom he here designates as Homer - as a sort of 'proto-paradoxographer'. ${ }^{2}$ In one of the relatively rare explicit authorial comments in his Collection Antigonus here praises the poet as 'in all respects desirous of knowledge and painstaking' ( $\pi \varepsilon \rho \tau t \tau \dot{v} v$ ö $v \tau \alpha)$. As Matthew Leigh has recently pointed out, these two terms take on an unusually positive sense here: rather than denoting a pedantic and useless sort of scholarship, as they do often elsewhere, they have become terms of approbation, reflecting a sense of intellectual and scholarly rigour on the part of the poet which could equally be extended to the art of the paradoxographer himself. ${ }^{3}$ In this way, Antigonus tries to cast Homer in his own image, making the poet into a sort of (accidental or otherwise) protos heuretes (first inventor) of paradoxography itself. Furthermore, by casting the poet in his own image in this way, Antigonus lays claim to the authority of the Homeric poetic tradition for the sort of inquisitive Aristotelian interest in natural wonders which the paradoxographer's collection espouses, almost as if the poet of the Hymn understood that there is 'something wonderful in all aspects of the natural world', even in the 'study of the lowest animals', long before Aristotle formulated it as such in his De partibus animalium (645aI5-I7). ${ }^{4}$

Antigonus is helped in his aim of fusing the Homeric and Aristotelian traditions by the fact that the line he cites does exhibit a sort of scientific concern prescient of the interests shown in Aristotle's biological works. The thing which allows Antigonus to link the poet to his claim that ewes produce more melodious gutstrings than rams is the detail that Hermes chose 'female sheep' $\left(\theta \eta \lambda \cup \varepsilon^{\prime} \rho \omega \nu\right.$ ói $\left.\omega v\right)$ rather than rams to string the first lyre. There is no other extant source for this claim about the relation between sex, gut-strings and sound, with the exception of a mention in a later paradoxographical collection, the Paradoxographus

${ }^{2}$ It is not uncommon for ancient authors to attribute Homeric Hymns to Homer, as Antigonus does here. See e.g. Thuc. 3.I04 and Ar. Av. $\Sigma$ ad. 575. On the widespread attribution of Homeric Hymns to Homer in antiquity, see Faulkner (20 I I) I75-8.

3 Leigh (2013) I 89-90 on Antigonus' citation of the hHerm. here, and pp. I 88-94 on Antigonus and 'the aesthetic of the paradoxographer' in general.

4 On this Aristotelian formulation in the De partibus animalium, see Chapter 3, Section 4. 
Palatinus (c. third century CE?), which uses Antigonus' collection as one of its sources. ${ }^{5}$ Despite the lack of evidence for this precise claim about the nature of gut-strings according to sex, this idea does have a sort of plausible Aristotelian flavouring. There is certainly plenty of interest in the differences between ewes and rams, and the differences between the sounds created by the voices of male and female animals, in Aristotle's biological works. ${ }^{6}$ Theophrastus of Eresus is even said to have produced a treatise entitled On the Different Sounds Produced by Animals of the Same

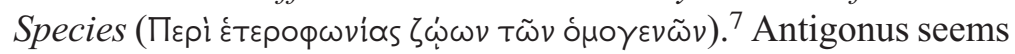
to have extended this Peripatetic interest here in order to make his claim even more marvellous: according to Homer, there is apparently not only a difference between the voices of male and female animals but even between the sounds their bodies make when used to provide the 'voice' of an instrument. ${ }^{8}$

The juxtaposition of the presentation of Homer as a sort of 'proto-paradoxographer' with the next marvel concerning

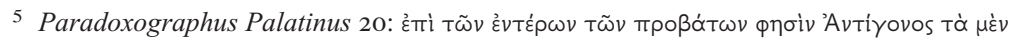

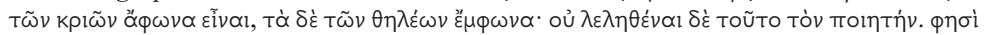

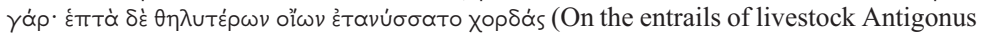
says that those of rams are unmelodious, while those of ewes are melodious. Nor did this escape the notice of the Poet [i.e. Homer]. For he says: 'He strung it with seven gutstrings from female sheep'). Clearly the author of the Paradoxographus Palatinus is using Antigonus' paradoxographical collection in order to present the same claim in a truncated form.

${ }^{6}$ On the differences between the sounds created by the voices of male and female animals in general, cf. e.g. Arist. Hist. an. 538bi2 (female animals have sharper and thinner voices than male animals, except for the cow, which has a deeper voice than the bull); $544 b_{3} 2$ (the female animal has a sharper voice than the male, and the younger animal has a sharper voice than the elder); 545a22 (male animals which are gelded assume the voices of their female equivalents); 58 IaI 7 (the voices of male humans begin shrilly but deepen upon maturation); $58 \mathrm{Ib6}$ (women have higher voices than men, younger women have higher voices than older women, boys have higher voices than men, and as a result girls' auloi are tuned more sharply than those of boys).

7 This treatise is mentioned as a work of Theophrastus at Athenaeus, Deipnosophistae 320a and Diog. Laert. 5.2.43.

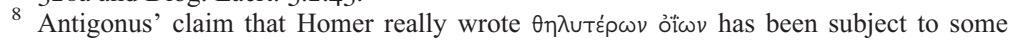

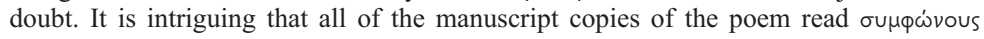
(harmonious) rather than $\theta \eta \lambda u \tau \varepsilon \dot{p} \omega \nu$ (female), a reading which only Antigonus transmits. Most editors and commentators have dismissed Antigonus' reading, usually on the basis

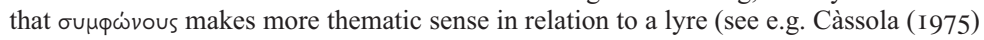
520; West (2003) I I6; Thomas (2020) I 70-3; Richardson (2010) I62). Vergados ((2007) 737-42 and (2013) 269-70) has recently proved the exception to this general tendency, supporting Antigonus' reading on the basis that paradoxographers tend to transmit their texts fairly faithfully. 
Philitas of Cos' knowledge about the type of deer bone needed for the manufacture of melodious auloi again demonstrates that the connections between entries in Antigonus' paradoxographical collection are both sophisticated and thematically motivated. Moreover, this entry also focuses on the wondrous creation of a 'living' voice out of a dead and voiceless animal. ${ }^{9}$ In contrast to the positioning of 'Homer' in the previous entry, the presentation of Philitas as another kind of 'proto-paradoxographer' with scientific interests which dictate his poetic output is perhaps less surprising, given the Hellenistic poet's reputation for scholarly

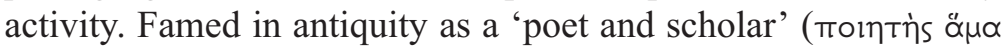
kœi kpıtıkós, Strabo, Geography I4.2.I9), Philitas certainly did exhibit an interest in philological and grammatical scholarship in the testimonia and fragments of writings relating to his work which remain to us. ${ }^{\text {Io }}$ But even so, Antigonus slightly exaggerates the Coan's status as a writer who prefigures his own paradoxographical and natural scientific interests, since there is no evidence from these relatively meagre remains that Philitas was chiefly interested in natural science in the same way as, for example, Aristotle was. That is not to say that Philitas was not at all interested in this kind of technical or scientific material concerning the natural world, just as many subsequent Hellenistic poets were, but it is clear that he cannot be held up as an obvious paradoxographical predecessor for Antigonus in the same way as a figure such as Aristotle or Callimachus can be. ${ }^{\text {II }}$

9 Antigonus may also be drawing a connection between the hHerm. and Philitas' poem here: both Spanoudakis (2002) 209 and Lightfoot (2009) 49 n. I2 suggest that Philitas' words may be from a sympotic context, as they seem to constitute a call for music on the aulos in a riddling form; the hHerm. can itself be seen as a sort of aetiological narrative for the future place of the lyre at the symposium. At the end of the first group of entries of his Collection Antigonus thus juxtaposes two examples of instruments which derive from the natural world and yet find a home in a later sympotic context.

1o On Philitas' life, works and famed status as the archetypal Hellenistic scholar-poet, see e.g. Pfeiffer (I968) 88-93, Sbardella (2000) 3-75, Dettori (2000) I9-49 and Spanoudakis (2002) I9-74.

II For example, in the fragment cited by Antigonus the use of тú $\mu \mu \alpha$ for thorn has been regarded as indicative of an interest in the use of medical terminology (see Sbardella (2000) I48, Spanoudakis (2002) 2 I 5 and Manakidou (20I2) I I 5). But, as Bing (2003) 342-3 points out, Philitas' interest in the relationship between the dead fawn and the cactus thorn in this fragment is probably predominantly lexical, and not paradoxographical or 'scientific' as Antigonus seems to suggest. 


\section{I Homer the Proto-Paradoxographer}

Antigonus is nevertheless keen to reinforce this impression: soon after the mention of the deer-bone auloi, the paradoxographer is even more explicit in his praise of his predecessor's supposed scholarly and scientific interests. A little later in the Collection of Marvellous Investigations, Philitas is again mentioned in connection with Antigonus' discussion of 'unusual similarities and differences between animal species and their ways of

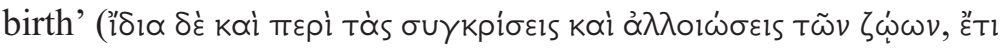
$\delta \dot{\varepsilon} \gamma \varepsilon v \varepsilon \dot{\varepsilon} \sigma \varepsilon 15$, I9). As his first example of this type of marvel, he plunges into a lengthy entry on a topic which is a staple of both paradoxographical collections proper and texts which aim at inducing a temporary paradoxographical flavour: the process known as bugonia, the spontaneous generation of bees from dead oxen. ${ }^{\text {I2 }}$ Antigonus begins this entry about the spontaneous generation of living creatures from dead animals by noting that 'if you bury an ox in certain locations in Egypt so that its horns protrude out from the ground, and then saw the horns off later, people say that bees

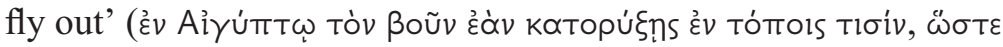

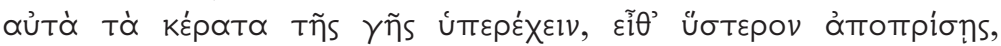

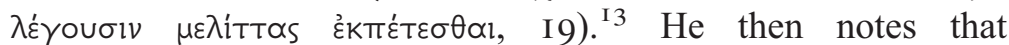
Philitas took a particular interest in this phenomenon precisely because he 'took trouble over things' ( $\omega ّ \nu \pi \varepsilon p i \varepsilon p \gamma o s, ~ I 9) ~-~ l i k e$ a paradoxographer himself, or so Antigonus seems to hint. Once again, we see that by using the literary texts of the past in this way to cast their authors as proto-paradoxographers, Antigonus is taking pains to invent a tradition for his own miscellanistic mode of writing. At the same time, this return to and reuse of familiar texts of the literary past allows the paradoxographer to offer a wondrous new view on these works which potentially surprises and stimulates our interest anew. Moreover, for Antigonus, the presence of these marvels buried within the texts of the past is itself part of the thauma of his own collection: the opening section

I2 Virgil's two versions of the generation of ox-born bees at Georgics 4.28I-3I4 and $4.538-58$ are of course the best-known poetic descriptions of the phenomenon in ancient literature: on Virgil and bugonia, see e.g. Kitchell (I989) I93-206, Habinek (I990) 209-23 and Morgan (1999) I05-49.

${ }^{13}$ For other epigrams on spontaneous generation attributed to Archelaus which Antigonus transmits along with Philitas' verses at Collection of Marvellous Investigations I9, see Chapter 3, Section 2. 
of the Collection of Marvellous Investigations thus not only hits upon the thaumatic potential of music but implicitly promotes the world of the text itself as an equally wondrous realm capable of preserving the paradoxographical interests of the past, present and future.

\subsection{Giving Voice to the Dead: Thauma and the Lyre in the Homeric Hymn to Hermes}

It seems then that Antigonus clearly saw the thaumatic potential of the hHerm. while compiling his collection of marvels. But what can we say about the place of thauma in the hHerm. itself? Hermes' stringing of the lyre with seven melodious (and possibly distinctly female) strings in line 5I of the Hymn, which Antigonus cites, is the culmination of a long description of the tortoise's wondrous transformation from voiceless living animal to inanimate, yet articulate object. This process begins with Hermes' first address to the tortoise at the moment he stumbles upon it by chance $(30-8)$ :

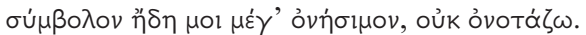

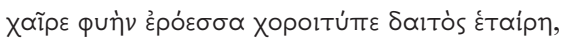

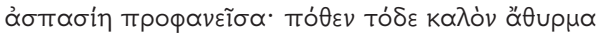

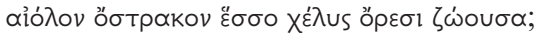

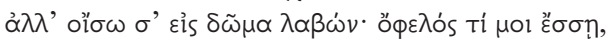

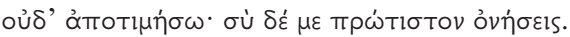

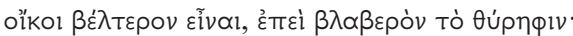

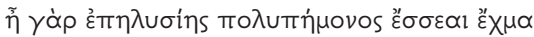

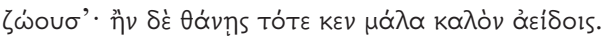

Here's a sign in front of me, a great source of profit: I do not dismiss it! Hail my companion of the feast who beats out the dance, lovely in form, welcome is your manifestation! Where did you get this beautiful plaything from, this dappled shell you have put on, tortoise living in the mountains? But taking you up I shall carry you into the house. You will be of some benefit to me, I shall not dishonour you. You will profit me first of all. 'Better to be at home, since outside is harmful' [= Hesiod, Works and Days 365]. For you will be a defence against woeful attack while you live, but if you die, then you will be able to sing beautifully.

Hermes' persistent anthropomorphisation of the tortoise is immediately clear from his initial address to the animal as his 
'companion of the feast who beats out the dance' (Xoportúrা

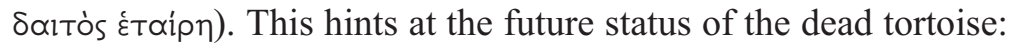
she will 'beat out the dance' as a lyre in symposia yet to come, a paradoxically energetic manoeuvre for a lifeless animal, and encourage dancing in others. There is a hint here as well that the tortoise has been eroticised and already cast as a sort of sympotic hetaira when Hermes first bumps into her seductively 'sashaying

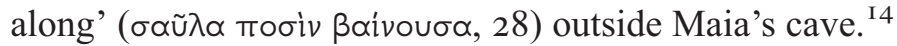

This anthropomorphisation of a living animal which will become a strangely vocal inanimate object reflects Hermes' famed ability to cross boundaries, since the lyre itself is an object which embodies the transgression of various conceptual borders. ${ }^{\mathrm{I}} 5$ The tortoise suits Hermes' purpose in this respect since it is already an animal which skirts boundaries by its very nature, as the infant god's speech makes clear. As a creature which paradoxically carries its own home on its back, the tortoise is constantly poised on the boundary between inside and outside, as Hermes' bantering use of the Hesiodic line 'better to be at home, since

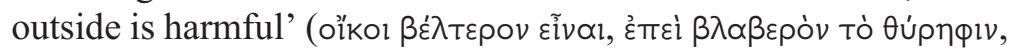
$36=$ Works and Days 365) draws out. ${ }^{16}$ Moreover, Hermes' promise to take the living tortoise which dwells outside in the

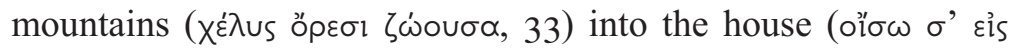
$\delta \tilde{\omega} \mu \alpha, 34)$, for Hesiod a place of safety, is undercut by the fact that the animal's transition into a lyre which is played indoors at the feast will involve prising it forcibly away from the home on its back.

The antithesis between inside and outside is not the only one which is overturned here. The tortoise is by definition a liminal animal which also hovers between the status of animal/hetaira and living/dead from the very moment of Hermes' first encounter with his future lyre. But it is the animal's ability to provide a living voice through its death that is emphasised most in the next section

I4 See Thomas (20I5) 364-5 and (2020) I 56; cf. Vergados (20I3) 248. For the continued eroticisation of the tortoise lyre later on in the Hymn, see lines 475-8.

I5 On Hermes' ability to cross borders in general, see Vernant (I983) I 27-75; on borders and Hermes in the hHerm. specifically, cf. Kahn (I978) and Clay (2006) 98-IO3.

I6 See Vergados (2013) 24 on Hermes' citation of the Works and Days and how it relates to the distinction between outside and inside which the tortoise inherently blurs in this Hymn. 
of hHerm, as Hermes sets about turning his 'lovely plaything' (

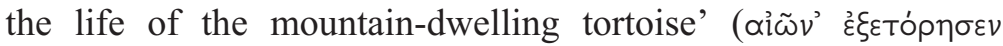

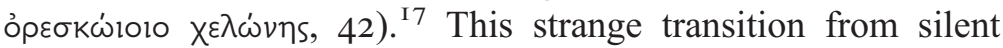
living animal to singing dead instrument is reinforced by the

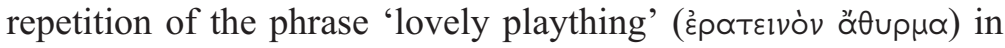
line 52 at the moment Hermes begins to play the lyre for the very first time. Hermes' opening address to the tortoise therefore clearly hints at her future function as an instrument. The importance of the tortoise's ability to sing beautifully in death, a quality

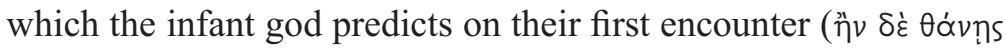

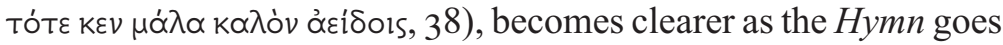
on, since we will see that the lyre possesses a voice which can be used in variety of contexts to make even the gods marvel, and which turns Hermes himself into a source of wonder. The hHerm. seems to suggest that the lyre inspires this thaumatic response at least in part due to its inherently paradoxical nature as a dead animal which is able to replicate the voice of an animate creature. $^{\mathrm{I} 8}$

The marvellous paradoxes surrounding the lyre's creation remain an important aspect of the literary tradition surrounding the instrument's invention by Hermes. Sophocles picks up on this in his version of the story of Hermes' theft of Apollo's cattle in the satyr-play Ichneutai. In this play the satyr-chorus' astonished and fearful reaction to the lyre is stressed several times. After being

17 Burkert (I983) 39 places an even greater significance on the connection between death and song here, claiming that '[a]ny new creation, even the birth of music, requires ritual killing. Underlying the practical use of bone-flutes, turtle-shell lyres, and the tympanon covered with cowhide is the idea that the overwhelming power of music comes from a transformation of and overcoming of death.' The paradox of the beautiful 'living voice' of an instrument emanating from the dead body of an animal is also present in the riddling lines referring to a conch-shell trumpet which Athenaeus cites

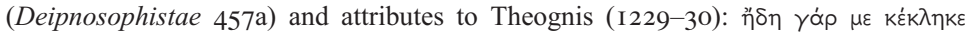

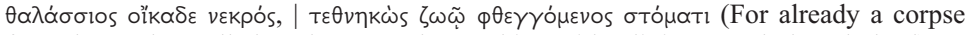
from the sea has called me homewards, speaking with a living mouth though dead).

18 There is perhaps a further note of irony here if the author of the Hymn is implicitly contrasting the unimpressive voices of real-life tortoises with the beautiful future voice of the tortoise-lyre. The nature of the voice of the tortoise was certainly a matter of interest in later Greek texts: Aristotle, for example, discusses animal voices at Hist. an. 536a and claims that all oviparous quadrupeds have weak voices, and the tortoise's voice in particular consists of a low hiss; on this and later Greek views concerning the tortoise's voice, see Vergados (20I3) 258. 
frightened by the overwhelming new sound of Hermes' instrument, the satyrs beg the nymph Cyllene to tell them 'who in the regions below the ground spoke wondrously with a divine voice' ( $\dot{\varepsilon} v$ тó то口

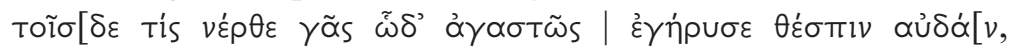
249-50). ${ }^{19}$ Cyllene replies that the contrivance they heard making the noise belongs to Hermes, whose astonishing abilities and incredibly swift growth over the course of six days are 'amazing', so much so that they have left the goddess gripped with 'wonder and fear'

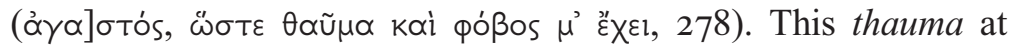
Hermes himself is paralleled by the satyrs' wonder at the lyre, a reaction caused in part by the paradox of the instrument's status as an inanimate object with a voice (299-300):

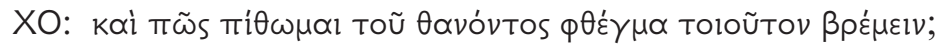

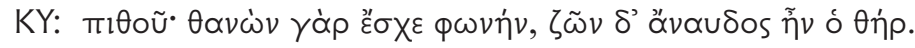

CHorus: Yet how am I to believe that such a voice roars out of something dead?

Cyllene: Believe it! The creature possesses a voice while dead, but while living it was voiceless.

The lyre even has the ability to create wonder by transforming the satyrs themselves into an astonishing visual and aural spectacle, as Cyllene's labelling of the satyr-chorus' new, unexpected and wild lyre-inspired choreia as a thauma suggests. ${ }^{20}$ In Ichneutai as in the hHerm. the lyre floats between various antitheses - living/dead, animate/inanimate, voiced/voiceless, animal/instrument - in a way which accounts to a great extent for its thaumatic effect. As noted in Chapter 2, the strange collapse of boundaries between animate and inanimate, and living and dead, is a primary means of creating wonder when it comes to gazing at visual objects; here the transgression of that boundary stretches into the aural realm as well.

I9 As noted by Lämmle (20I3) 432-5, the wonder and fear of the Ichneutai's satyr-chorus at the acoustic effects of this 'voice from below the ground', and the riddling effect of their subsequent stichomythia with Cyllene, is at times suggestive of ancient mystery cult.

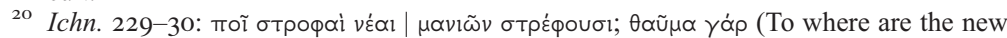
whirlings of madness whirling you? It is a wonder!). I am grateful to Rebecca Lämmle for drawing my attention to the significance of these lines. On the satyr-chorus' novel choreia here, see Lämmle (20I3) 232-3 and (20I9) 34-5. 


\subsection{Hermes' Signs and Songs: Thaumata and Semata}

But how is the potentially wondrous aural effect of the lyre articulated in the hHerm.? Over the course of the Hymn, the marvellous results of Hermes' performances with the lyre are increasingly emphasised. Immediately following the description of the stretching of the sheep-gut strings which Antigonus later cites in his paradoxographical collection comes the account of Hermes' first performance (52-9):

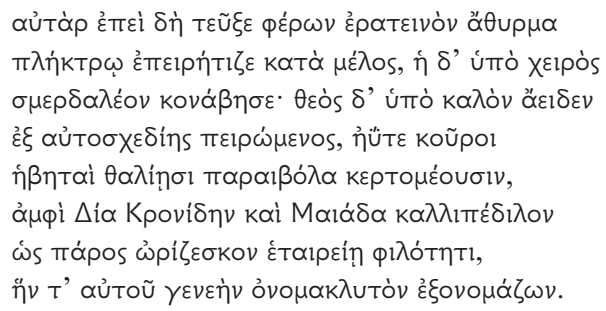

But when he had crafted it, after taking up the lovely plaything he started to try it out in a tuned scale with a plectrum, and by his hand it resounded terrifyingly. And the god tried it out improvisationally and sang beautifully in accompaniment, just as young men in the prime of youth taunt each other with banter at feasts: he sang about how Zeus son of Cronus and Maia with beautiful sandals used to flirt with friendly intimacy, and named his own renowned lineage.

The simile describing Hermes' first experimental song again hints at a possible sympotic context for the future use of the lyre, just as Hermes' initial teasing address to the tortoise prefigured the future use of the instrument. Now during the god's first performance his extempore singing is compared to the impromptu sung banter which young men hurl at each other at the symposium. It is not such banter, however, which Hermes goes on to offer in this case, but a hymn very much like the $h$ Herm. itself. ${ }^{2 \mathrm{I}}$ Hermes must sing for himself because as an infant god who has not yet confirmed his place among the Olympians (at least in the eyes of the other gods), he does not seem, at least at this point in the narrative of the poem, to have anyone (human or otherwise) to sing praises of what the poet will soon come

${ }^{21}$ For example, Hermes' hymn here begins with his own conception and an account of his lineage, just as the hHerm. itself begins with the conception of the god (see lines 3-I2). On the strongly hymnic features of Hermes' first song, see Vergados (20I3) 4-I2 and Thomas (2020) I77-8I. 


\subsection{Hermes' Signs and Songs: Thaumata and Semata}

to term his thaumata erga ('wondrous deeds', 80, 440). His own description of Maia's seduction by Zeus thus provides him with a weighty genealogy and acts as implicit self-praise which justifies his claim to a place on Olympus. ${ }^{22}$ This also creates a mise en abyme effect, as the poet of the hHerm. describes Hermes performing nothing other than the present hymn to Hermes. I will return to the significance of this mise en abyme effect for the thaumatic power of the Hymn as a whole below, but for now it is worth turning to the other thaumata erga which Hermes undertakes before he picks up his lyre and sings for the second time.

Before we reach Hermes' second thaumatic performance it is made clear that the young god's verbal thaumata are repeatedly and explicitly paralleled by his ability to manipulate visual semata (signs) throughout the narrative. This ability to exploit semata is enabled by Hermes' facility for the creation of marvellous inventions which combine previously disparate familiar objects of the natural world: first the lyre, and then the deceptive sandals which allow the infant god to mislead Apollo in the search for his cattle by further confusing the twisting tracks which Hermes has forced the livestock to create by walking backwards. ${ }^{23}$ The sandals are ingeniously created through the connection of disparate parts and specifically parallel the lyre in their wondrous effect as objects of Hermes' skill (metis). ${ }^{24}$ In fact, they are first explicitly named as thaumata at the very moment of their creation (79-8I):

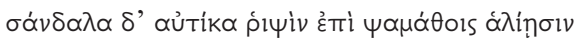

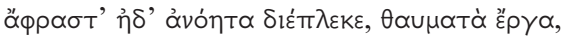

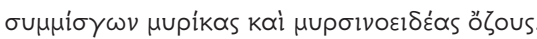

Immediately on the sands of the seashore he began to weave together sandals, unthought of and unimaginable, marvellous works, mixing together tamarisk and myrtle twigs.

Hermes' thaumata erga and the poet's own art are here aligned, as innovative and unusual compound words ( $\alpha \rho \rho \alpha \sigma \tau$ ' $\left.\eta \delta^{\prime} \alpha \alpha \nu o ́ \eta \tau \alpha\right)$

22 See Vergados (20I3) 4-5.

23 On the relationship between Hermes' wondrous inventions, see Clay (2006) II3: 'Hermes' sandals, the $\theta \alpha u \mu \alpha \tau \dot{\alpha}$ हैp $\alpha$, resemble the god's other inventions in that disparate things ... are joined together ... to produce something new and unheard of.'

24 On thauma as a natural reaction to metis in the hHerm., see Kahn (I978) Io6-9 and Clay (2006) I3 I-2. 
are used to express the novelty of Hermes' invention. ${ }^{25}$ By this point in the narrative we might already begin to suspect that the bard of the hHerm. is as inventive as Hermes: the creation of the sandals is one of the first hints that we are meant to wonder at the bard's thaumata erga most of all in this Hymn.

The parallel created between the wondrous sandals and the wondrous lyre is reinforced further by the fact that a few lines

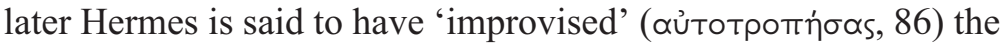
sandals, just as his invention of hymnic song on the lyre arises in

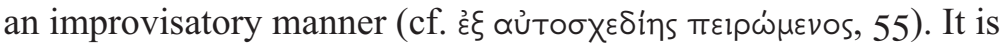
Hermes' ability to make something appear out of nothing, to metamorphose a product of culture out of nature, which creates a sense of wonder in those who are on the receiving end of such transformations. But it is not only the inventions themselves but also the products and the effects they facilitate that cause thauma in this Hymn. In the case of the lyre, these products consist of the instrument's melodies and the vocal performance it enables; in that of the sandals, the concealment of the cow tracks and the increase of confusion this entails.

We see this in action when Apollo is explicitly struck by wonder at the semata which Hermes' invention has created during the cattle rustling (2 I 8-25):

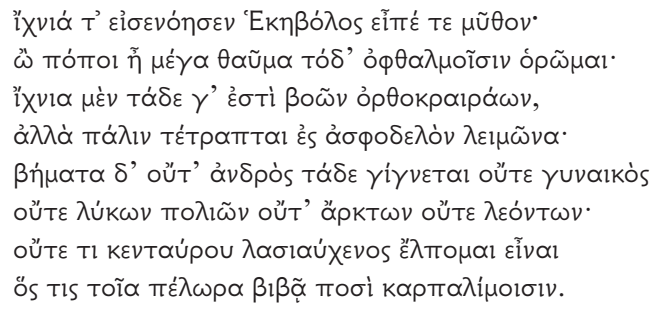

And the god who shoots from afar noticed the tracks and said: 'Oh! What a great marvel I see with my eyes! These are indeed the tracks of the straight-horned cattle, but they are turned backwards towards the asphodel meadow. And these footsteps come from neither a man nor a woman nor grey wolves nor bears nor

25 Shelmerdine (I98I) I I I suggests that the poet is using deliberately novel adjectives to

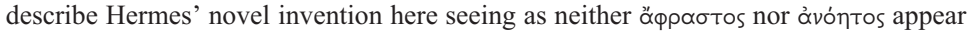
anywhere else in Homer, Hesiod or any of the other Hymns. 


\subsection{Hermes' Signs and Songs: Thaumata and Semata}

lions. Nor do I think that a shaggy-necked centaur is the one who makes such monstrous tracks with his swift feet'.

Apollo's exclamation at the sight of the tracks plays with thauma in an especially rich manner. The formulaic line 'Oh! What a great

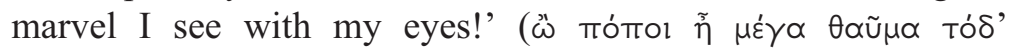
ỏ $\phi \alpha \lambda \mu о \tilde{\sigma} \sigma v$ ó $\tilde{\omega} \mu \alpha)$ is uttered only by mortals in the Iliad and the Odyssey, often as a result of the recognition of divine presence. $^{26}$ Throughout the hHerm. Apollo's ceaseless wonder at Hermes' works is reminiscent of the marvelling response of mortals at the actions or presence of gods. ${ }^{27}$ As well as contributing to the humorous tone of the Hymn as a whole, the fact that Apollo reacts to Hermes' actions in a typically 'mortal' way emphasises that the young god is actually worthy of his place on Olympus after all, as his fellow god reacts to his deeds with awe. This is later confirmed when Apollo's initial astonishment at the misleading semata created by the cattle and Hermes' marvellous shoes is reiterated by his later description $(342-3)$ of the confusing cattle's trail created by the infant god: 'the tracks were doubly monstrous, the sort of thing worthy of wonder, the work of a glorious god' (

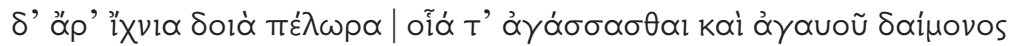
है $p \gamma \alpha$ ). The monstrous and wondrous tracks thus prompt Apollo's recognition of Hermes' non-mortal nature for the first time by creating a feeling of wonder reminiscent of the way mortals react to divine epiphanies. ${ }^{28}$ It is by wielding the power of thauma, then, that Hermes is able to turn the tables on his elder brother and firmly

${ }^{26}$ Cf. Il. I5.286, where this line is uttered by the Achaean Thoas, who is amazed that Hector has survived Ajax's attack and realises that one of the gods has saved him (TIS

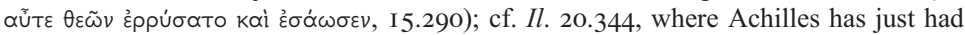
a mist shed over his eyes by Poseidon and is amazed that his spear has missed Aeneas, whom he (rightly) assumes must be dear to one of the immortal gods. Cf. also the slight variant of this line at $O d$. I9.36, where Telemachus says 'Oh father! What a great marvel

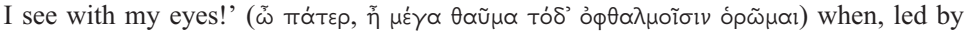
Athene, he sets off with Odysseus to remove the shields and helmets from the hall before they kill the suitors and sees the house glowing, with the result that he supposes that there is 'surely one of the gods who hold wide heaven inside' ( $\tilde{\eta} \mu$ 'ó $\lambda \alpha$ Tis $\theta$ ròs

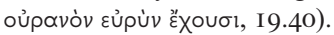

27 On the unusual nature of the way in which Apollo reacts with thauma not only at the visual effect of Hermes' deeds but even to the very sound of Hermes' performance on the lyre, see Lather (2017) I40-4.

${ }^{28}$ See Vergados (20I3) 463-4; cf. Turkeltaub (2003) 3I-2 on thauma as an element of epiphany scenes in epic poetry and Platt (2OI I) $56-7,64-5,68-72$ on thauma and divine epiphany in general, especially in the Homeric Hymns. 
assert himself as the more powerful god at this point in the Hymna paradoxical achievement given that Hermes is still only one day old.

The marvellous semata created by the combination of the deceptively reversed cow tracks and Hermes' wonderful shoes are structurally parallel with the marvellous product of his other thaumatic invention in the poem: the music of the lyre and the song which accompanies it. ${ }^{29}$ Both the visual semata and the musical performances are thaumata produced by Hermes, and both are types of epiphanic manifestations of the god's power. The effect of Hermes' first performance on an audience is not made clear to us within the Hymn, as no internal audience is present. This is possibly a reflection of his stature at this early point in the poem, since the infant god has not yet gained enough power to command an audience of his fellow gods. ${ }^{30}$ This is not the case, however, after Hermes' second performance, where we find the lyre's future patron, Apollo, praising the astonishing musical performance in the strongest terms $(439-46)$ :

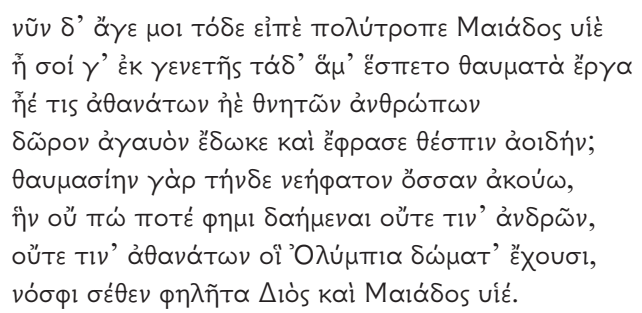

But now come on and tell me this, son of Maia with many wiles: did these marvellous works follow straight from your birth, or did one of the immortals or one of mortal men bestow this glorious gift and show you divine singing? For I hear this marvellous newly-spoken/newly-slain voice, which I say that no mortal or immortal who holds Olympus has ever yet learnt, with the exception of you, tricky son of Zeus and Maia.

Apollo's first mention of Hermes' 'marvellous works' relates both to his preceding song, as the reference to his 'divine singing'

${ }^{29}$ Cf. Steiner ( I 994) 44 on the lyre and the cattle tracks as the two 'message-bearing tokens of the first half of the poem'.

${ }^{30}$ See Clay (2006) I03-5I and Vergados (2013) 4-5 on Hermes' process of maturation and its relation to his two songs in the hHerm. 


\subsection{Hermes' Signs and Songs: Thaumata and Semata}

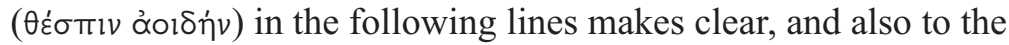
'glorious gift' ( $\delta \tilde{\omega} \rho \circ v$ ả $\gamma \alpha u o ́ v)$ of the lyre itself. It also covers all of the infant Hermes' other inventions and actions in the Hymn. But at this point, the particular cause of Apollo's present wonder is the 'wondrous voice' ( $\theta \alpha u \mu \alpha \sigma i \eta \eta . . . ~ o b \sigma \sigma \alpha v)$ of the instrument he has just heard. ${ }^{3 \mathrm{I}}$ The quality of this wondrous voice is described as vहnंфatov, a word which, as Oliver Thomas has pointed out, could mean both 'newly-slain' and 'newly-spoken'. ${ }^{32}$ Once again, the lyre's ability to straddle boundaries is what lends it its thaumatic power. In the hHerm., this power is something that affects even gods. This is important, since elsewhere in the Homeric Hymns thauma is a topos of the human response to, and recognition of, the epiphanic revelation of god to man. ${ }^{33}$ The $h$ Herm. self-reflexively turns this topos on its head: Hermes' powerful performance is the final piece of evidence which ensures Apollo's recognition of his younger half-brother as a god truly deserving of his place on Olympus. The very end of Apollo's long praise of Hermes reinforces the importance of thauma in this process of quasiepiphanic revelation and recognition when the god once again returns to the astonishing nature of the performance he has just experienced in line 455: 'I am astonished, son of Zeus, at how

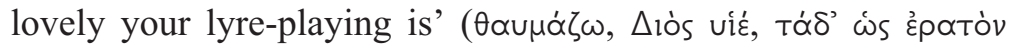
kı $\theta \propto p$ í $\varepsilon 1 \zeta)$. Wonder, then, is certainly the keynote effect of Hermes' musical performances as a whole, as Apollo's repeated emphasis on his astonished response demonstrates. Furthermore, since this is an aetiological narrative about the invention of the lyre, the hHerm. suggests that this wonder carries over into every subsequent divine or human performance with the instrument. This, I suggest, is really where the power of wonder and divine

${ }^{31}$ On the particular association of the word ö $\sigma \sigma \alpha$ with the divine, see Ford (I992) I75-6.

32 See Thomas (2020) 389.

33 On thauma as a usual response to divine epiphany in the Homeric Hymns, see especially Platt (20II) 64-70 and Richardson (20I0) IO2 on $h A p$. I34-9. For examples from the Hymns, cf. Anchises' sense of wonder at Aphrodite's sudden appearance before him (despite the fact that she initially presents herself in human form) at $h A p h$. 84-5, Dionysus' wondrous manifestations (line 34) and the pirates astonished response (line 50) in the hDion., and the Cretan sailors' wonder at Apollo in dolphin guise at $h A p$. 4I4-5. 
epiphany in the hHerm. comes into play, as the next section will demonstrate.

\subsection{Collapsing Boundaries: Epiphanic Thauma, Choreia and Song}

Unlike the other major Homeric Hymns, the hHerm. does not describe to its audience a moment of epiphanic and wonderinducing revelation of god to mortal within the narrative itself. ${ }^{34}$ In other Homeric Hymns, in particular those to Demeter (2), Apollo (3), Aphrodite (5), and Dionysus (7), epiphanic thauma is indeed a constant keynote of the meetings of gods and mortals. Why, then, is thauma not explicitly connected to the epiphanic revelation of the titular god to mortals in the hHerm.? It seems that the answer lies in the nature of Hermes himself in this Hymn. Since Hermes is a figure who delights in boundaries and who has not yet quite proven his own place on Olympus at the beginning of the narrative, it is fitting that he is hymned in a way which probes the boundaries between mortal and divine much more intensely and self-referentially than other hymns through the mise en abyme effect employed, which also makes the god's wondrous inventions obvious paradigms for ritual and sung praise of the gods in the real world. Another way in which the Hymn self-referentially explores the boundaries between the realms of gods and mortal is by depicting thauma as a paradigmatic response to music and as a signifier of the meeting point between the divine and human realms.

We also see this in the Odyssey when the poet describes Odysseus' wonder at the skilful dancing of the Phaeacian youths, accompanied by the bard Demodocus' lyre-playing. This scene becomes an archetypal depiction of the astonishing effects of marvellous choreia on its audience $(8.26 \mathrm{I}-5)$ :

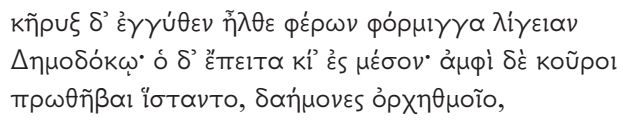

34 On the unusual treatment of the epiphany theme in this poem, see Vergados (20II) 82-IO4 and Cursaru (20I2) 42-8. 


\subsection{Epiphanic Thauma, Choreia and Song}

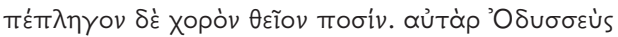

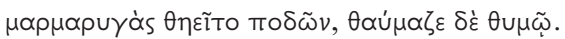

And the herald approached bearing the clear-voiced lyre for Demodocus. And he then moved into the middle, and the boys in the prime of youth, skilled in dancing, took up their positions around him, and they struck the sacred dancing floor with their feet. And Odysseus was gazing at the flashing of the feet, and he was marvelling in his heart.

The Phaeacians' excellence and frequent indulgence in choreia, like their love of constant and carefree feasting, is one of the most notable manifestations of their suprahuman qualities and uncanny closeness to the gods. ${ }^{35}$ The wondrous effect that the blurring of the boundaries between the mortal and human realms is able to provoke is similarly depicted in the Homeric Hymn to Apollo, where the description of the marvellous performance of the Delian Maidens depicts the potential which the thauma of successful human choral activity has to mediate between the realms of men and gods (I49-64):

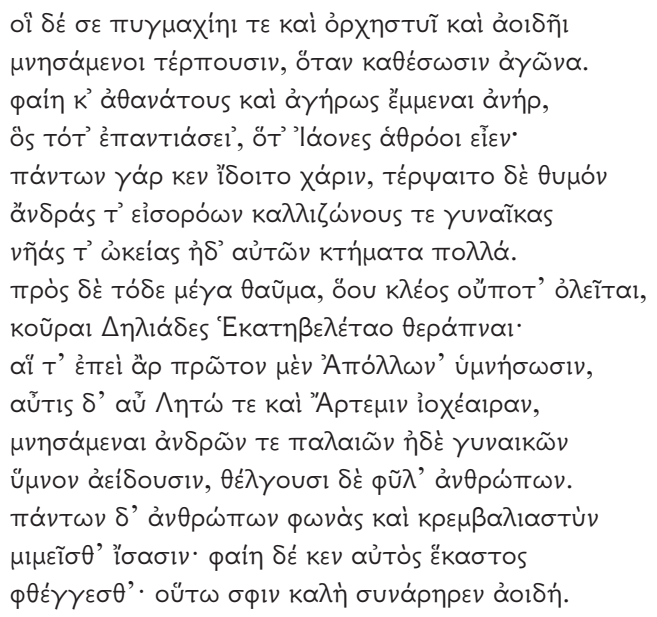

And mindful of you [Apollo] they [the Ionians] delight you with boxing and dancing and song, whenever they have set up a gathering. A man present then when the Ionians are gathered would think that they were immortal and unaging:

35 On Demodocus' lyre-playing and the dance of the Phaeacians as the archetypal scene of wonder-inducing choreia, see e.g. Power (2OII) 82-5, Kurke (2OI2) 228 and (2OI3) I 53-4, and Olsen (20I7) 5-I I. 
he would see the charm of everything, and be delighted in his heart while looking at the men and the women with beautiful girdles, and the swift ships and their many possessions. And in addition there is this great wonder, the fame of which will never come to an end: the Delian Maidens, servants of the Far-Shooter. After they have first hymned Apollo, they then in turn hymn Leto and Artemis pourer of arrows, and then mindful of the men and women of the past they sing a song, and they enchant the tribes of men. And they know how to imitate the voices and rhythmic rattling of castanets of all men. Each man would think he himself is speaking - so beautifully does their song hang together. ${ }^{36}$

In the $h A p$. the events of the Ionian festival on Delos are focalised through the eyes of a deliberately anonymous 'everyman', a hypothetical spectator who demonstrates the desired and ideal effect that witnessing the festival and the accompanying performance of the Delian Maidens would have on anyone who happened to be present. Within the ritual space of the festival, the Ionian

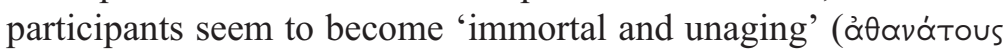

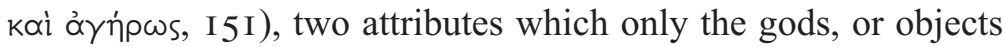
created by the gods, can truly possess. ${ }^{37}$ The Ionians are thus portrayed as closer to the gods than mortals ordinarily are during the festival itself, seemingly occupying a liminal space between gods and men (similar to the state of the Phaeacians in the Odyssey) which the ritual activity in honour of Apollo has opened up. ${ }^{38}$ Moreover, the Delian Maidens' wonder-provoking performance creates an impression of divine presence which draws the audience in and causes the Ionian spectators to 'fuse' or 'merge' in some sense with the choreuts themselves. ${ }^{39}$

This ability which the thauma arising from song, dance and music for the gods has to create a space within which the divine and human realms might touch upon one another is thus essential to the self-reflexive workings of the hHerm. as a narrative which both describes and enacts the confirmation of the young Hermes'

${ }^{36}$ Here reading $к \rho \varepsilon \mu \beta \propto \lambda \lambda_{1} \propto \sigma \tau u ́ v$ ('rhythmic rattling of castanets') rather than the common

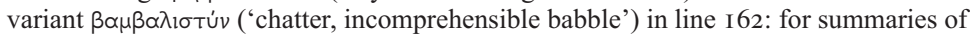
the arguments for the former and against the latter, see Peponi (2009) 4I-60.

37 See Kurke (2012) 225 on the overtones of divinity associated with this phrase in early hexameter poetry.

${ }^{38}$ On the features of Phaeacia in the Odyssey which suggest a festival setting involving poetic contests, see especially Ford (I992) I I6-20.

39 See especially Kurke (20I2) 223-4 and (2013) I46-60 on the significance of thauma in the $h A p$. for the creation of this kind of impression of divine presence. 
status as a divinity. This is because a human performance is conceived of as a fragment or echo of an eternal, divine music just as the Phaeacians' endless dance, song and feasting echo the enviable and marvellous lifestyle of the gods, so too does mortal choreia, especially in a festival context, simultaneously represent and provide a form of vicarious access to the gods' wondrous musical activities. For this reason Hermes' wondrous lyreplaying, with its ability to astonish even the gods, is simultaneously one of the means by which he eventually proves his right to inhabit the divine rather than the mortal realm, and a mode of playfully signalling the young god's temporarily indeterminate status, as he partakes of an activity seemingly more befitting the human realm and hymns himself with the lyre. Furthermore, thauma is associated within the narrative of the hHerm. not with the description of a god's revelation to a mortal, but with the inventions and actions of Hermes himself. Since the lyre is the foremost of these inventions it becomes visually manifest evidence of Hermes' power and symbolic of the thaumatic power of the entire bardic tradition. The thauma associated with the manifestation of a god is thus transferred to the instrument itself, and the aetiological nature of the Hymn makes clear that all subsequent lyre performances partake of this effect. Moreover, the mise en abyme effect created by the two wondrous performances described in the narrative further reinforces this effect. For this reason, as the Hymn progresses, it becomes clear that we are ultimately supposed to wonder at the epiphanic embodiment of Hermes we see made manifest before us as the Hymn is performed: the singer himself. By performing the Hymn the bard brings the realms of men and gods closer together by becoming a visually manifest stand-in for Hermes the lyre player. The audience's marvelling response to the bard is thus a reflection of Apollo's wondering response to Hermes, and vice versa. ${ }^{40}$

This sense that a solo performer may in some manner represent a wondrous epiphanic manifestation of a god through the medium of musical or poetic performance is not confined to the hHerm.

$4^{\circ}$ Cf. Vergados (20I3) I3: 'If the god's song causes wonder in his audience, the poet's performance lays claim to a similar effect.' 
alone. In Herodotus' Histories, this wonder-inducing aspect of music and song is strongly hinted at in another literary representation of lyre-playing: the famous story of Arion and the dolphin (I.23-4). At the very beginning of this account, Herodotus describes the well-known narrative concerning the abduction, sea dive and subsequent rescue of the citharode Arion by dolphins as a 'very great wonder' $(\theta \tilde{\omega} \mu \alpha \mu \varepsilon \dot{\varepsilon} \gamma l \sigma \tau o v$, I.23) $){ }^{4 \mathrm{I}}$ The reasons for this wonder become clear in the description of Arion's musical performance at Histories I.24. Here the marvellous collapse of firm boundaries between humans, gods and animals is described in a way which makes us reflect further on the nature and effect of musical performance in Greek thought. This begins when Arion beseeches the pirates to allow him to dress himself in his citharodic costume and sing on the quarter deck of the ship's stern before killing himself as they have demanded:

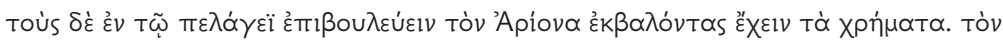

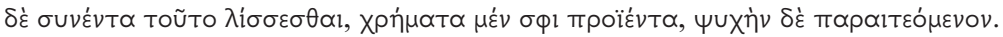

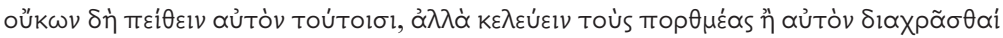

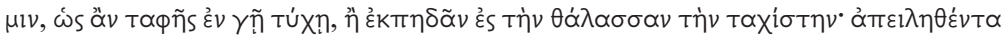

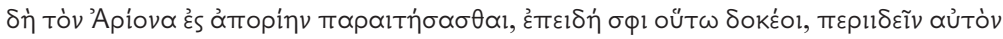

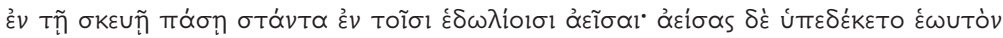

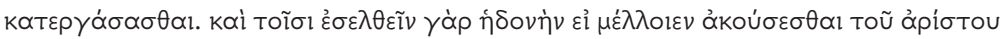

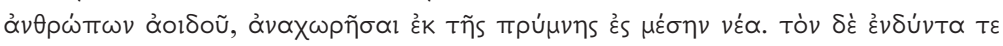

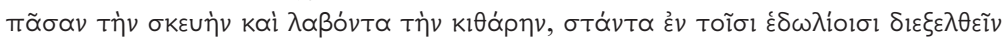

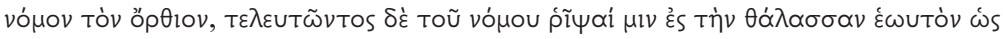

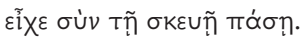

But when they were at sea, the pirates plotted to throw Arion overboard and take his money. When he realised this, he entreated them and offered his money to them, begging for his life. But he did not persuade them: instead the sailors ordered him to either kill himself, so that he might be buried on land, or to cast himself into the sea immediately. Arion, being between a rock and hard place, begged them (since their will was such) to allow him to stand on the quarterdeck in his full citharodic costume and sing. And after singing, he promised, he would finish himself off. The sailors, pleased by the opportunity of hearing the best singer in the world, withdrew from the stern to the middle of the ship. Arion, after putting on his full garb and taking up his cithara, stood on the quarterdeck and went through the nomos orthios [a high-pitched song in honour of Apollo] in full,

$4 \mathrm{I}$ On the significance of wonder in Herodotus' account of the Arion story, see Munson (200I) $25 \mathrm{I}-5$. 
and after finishing the nomos he cast himself into the sea clad in his full citharodic costume.

The emphasis placed on Arion's appearance in this passage is striking. The fact that Arion performs these actions in his complete citharodic costume (skeue) is stressed no fewer than three times (

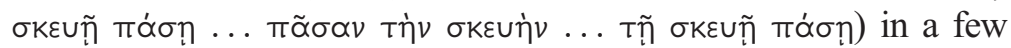
lines. ${ }^{42}$ This suggests that his visual appearance is as significant as the music which emanates from the lyre. ${ }^{43}$ Here we once again catch sight of the original visual reference of thauma: it is not the aural aspect of Arion's song alone which provides its wondrous impact, impressing the pirates and drawing the dolphin towards him, but the whole sensory experience of the citharodic performance.

The importance of the combination of the visual and aural aspects of Arion's performance becomes clear once the potential meaning of his citharodic skeue is examined. Timothy Power has suggested that the citharode's skeue is not only essential in marking the performer out from other people and signifying that he is 'a musical magician capable of wonders' but that the skeue even suggests that the musician is to be seen for the duration of the performance as some sort of epiphanic manifestation of a god (in this case, Apollo). ${ }^{44}$ Several details in Herodotus' description of Arion's reappearance after his marvellous dive and rescue reinforce this suggestion (I.24):

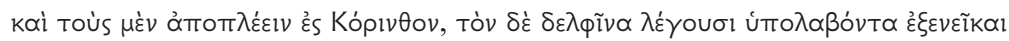

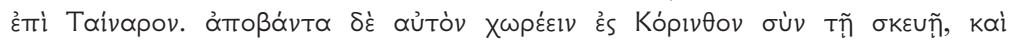

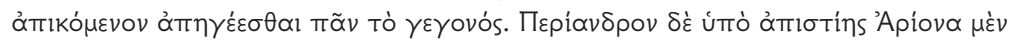

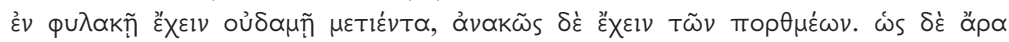

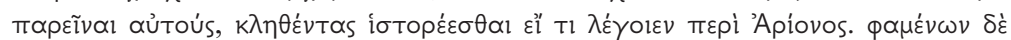

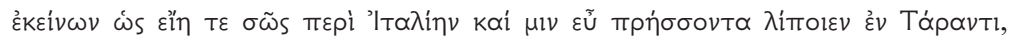

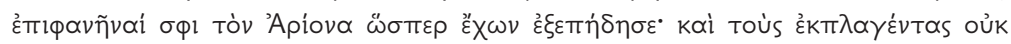

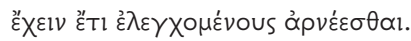

And the pirates sailed away to Corinth, but they say that the dolphin picked Arion up on its back and dropped him off at Taenarum. After landing there he went to

42 On the unusual nature of Herodotus' repeated emphasis on Arion's skeue, see Power (20I0) 25-7, Gray (200I) I4-I5 n. I 5 and Herington (I985) I6-I7.

43 Cf. Power (20I0) I I: 'A powerful visual impact is made even before the music begins. The kithara alone inspires wonder and curiosity.'

44 See Power (20I0) 25. 
Corinth with his citharodic costume and on arrival narrated everything that had happened. Periander, being of a naturally suspicious disposition, put him under guard and did not release him, and kept a careful eye out for the sailors. When they arrived, they were summoned and asked if they had anything to say about Arion. After they said that he was safe in Italy and that they had left him doing well at Taras, Arion appeared, looking just as he did when he had leapt overboard. And the pirates were astonished and, being confuted, were not able to deny it any longer.

It seems then that Herodotus is playing here with various senses and causes of wonder in his description of this 'very great wonder' $(\theta \tilde{\omega} \mu \alpha \mu \dot{\varepsilon} \gamma l \sigma \tau o v, I .23)$. First, he explores the nature of seemingly unbelievable stories and the marvelling reaction they provoke.

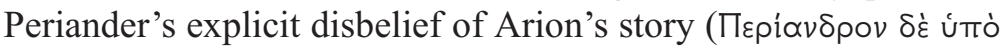
ởrlotins), and his testing of both Arion and the pirates, echo the reader's potential scepticism concerning Herodotus' own narration of thaumata in the Histories. The fact that Arion's story turns out to be true, despite the seemingly unbelievable element of his rescue by a dolphin, is a warning to us at this early point in the Histories to be careful about our own potential disbelief of Herodotus' more unlikely accounts. ${ }^{45}$

Furthermore, Herodotus again draws attention to the citharodic

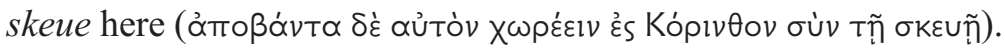
It is specifically as a citharode with all his accoutrements that Arion approaches Periander's court, and it is in his citharodic skeue that he will confront the pirates once again. The sense that there is something godlike in the appearance of the musician is also emphasised by the fact that the moment of Arion's reappearance is explicitly staged as a sort of quasi-divine epiphany

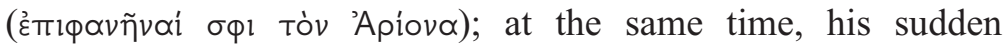
reappearance causes a natural sense of astonishment purely due to the fact that the pirates think that he is already dead - are they afraid because they think Arion is a god, or a ghost, or both ${ }^{46}$

45 On the way in which Periander's initial disbelief tallies with the reader's (and possibly Herodotus' own) initial scepticism about Arion's story, see Packman (I99I) 400; cf. also Munson (200I) 252.

46 See Power (2010) 27: 'The second surprise appearance of Arion in front of the sailors is configured as a divine epiphany - specifically, Arion in the fullness of his citharodic persona resembles none other than Apollo kitharoidos.' Cf. Lonsdale (1993) 93-4 on the 'quasi-divine status' of Arion in Herodotus' tale and Munson (200I) 253 on Arion's status as 'an almost sacral figure' in Herodotus' account. 
Arion therefore transgresses several seeming boundaries with his sudden epiphany here, being both alive and dead, human and divine. No wonder the pirates are astonished. Moreover, the result of Arion's sudden appearance is the same as the archetypal response to divine epiphany itself: astonished wonder and paralysing fear, as

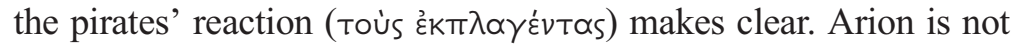
just a human singer in the moment of his citharodic performance of a nomos to Apollo, but a representation of the god himself, who allows those watching and listening to access, in some sense, the divine realm.

This becomes clear from another aspect of the Arion story. Just as thauma is presented as an integral aspect of the birth of both the hymnic genre and the later sympotic uses of the lyre in the hHerm., so too is it shown to be an essential aspect of the aetiology of dithyramb itself in book I of the Histories. In Herodotus' account Arion is presented as the protos heuretes of this mode of song: 'the first man of those we know who made and named the dithyramb

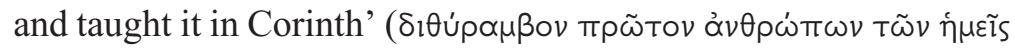

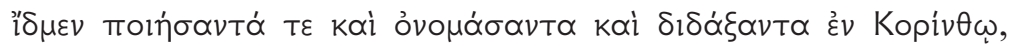
I.23). ${ }^{47}$ Arion's status as a marvellous performer in Herodotus' account suggests that thauma implicitly bleeds over into the genre of dithyramb itself. ${ }^{48}$ As both an emotion and cognitive state which, in Richard Neer's terms, inherently acts as a 'synapse' between outside and inside, wonder becomes in this way the paradigmatic response to music and song which brings gods and men into closer contact with one another. Thauma is the response

47 See D'Alessio (20I3) I I3-I 8 for a discussion of what this passage means in relation to the genesis of dithyramb; on the relation between Herodotus' passage about Arion and his aetiology of the dithyrambic genre, see Lonsdale (I993) 93-4, Csapo (2003) 9I-2, Csapo and Miller (2007) IO-I I, Steiner (20I I) 304, Pavlou (20I2) 5I7-I8, Kowalzig (20I3) 34, and Hedreen (20I3) I87.

48 In Bacchylides I7, thauma plays a similarly important role in the aetiological account of the paean, with Theseus' wonder-inducing reappearance on the deck of the ship after his dive into the sea framed as a marvellous quasi-divine epiphany. Theseus' astonishing reappearance, like the typical epiphanic appearance of a god, is a cause of "wonder for everyone' ( $\theta \alpha \tilde{u} \mu \alpha \pi \alpha \dot{\alpha \tau \varepsilon \sigma \sigma l, ~ I 23) ~ w h o ~ w i t n e s s e s ~ i t ~ a n d ~ c a n ~ b e ~ r e a d ~ a s ~ a n ~ a e t i o l o g y ~ o f ~ t h e ~}$ paean itself because it acts as the immediate cause of the outbreak of the Athenians' choral song within the poem and casts Theseus as a de facto choregos (see Calame (I996) 207-8, Fearn (2007) 255, and Pavlou (2012) 537 n. 95 on Theseus as choregos in Bacchylides I7; cf. also Hedreen (20 I I) 494 on the depiction of Theseus leading a dance as choregos on his arrival in Crete on the François Vase). 
The Sound of Thauma: Music and the Marvellous

that this blurring of the boundaries between mortal and divine provokes, and as a result it becomes integral to all subsequent acts of ritual music-making, dance and song. ${ }^{49}$

49 See also Ford (I992) 6, 55, 9I, I95-6, 200 on the audience's experience of epic performance as a kind of 'divine epiphany'. 